\title{
SURFACE VELOCITIES OF DENMAN GLACIER, ANTARCTICA, DERIVED FROM LANDSAT IMAGERY
}

(Abstract)

by

N. Young

(Australian Antarctic Division, Channel Highway, Kingston, Tasmania 7050, Australia)

Glacier velocities have been measured using satellite imagery by scaling and comparing photographic images that have been acquired over time intervals of about 10 years (e.g. Lucchitta and Ferguson, 1986). A pilot project was undertaken on Denman Glacier to develop techniques for the measurement of glacier velocities directly on the original digital image data rather than on photographic products, and to determine the potential accuracy of the results. Denman Glacier is clearly discernible in Landsat images as a well-defined ice stream from south of Mount Strathcona $\left(67.5^{\circ} \mathrm{S}, 99.2^{\circ} \mathrm{E}\right)$ through to the northern boundary of Shackleton Ice Shelf $\left(65.3^{\circ} \mathrm{S}, 99^{\circ} \mathrm{E}\right)$, a distance of $250 \mathrm{~km}$. There are surface features visible along most of its length which persist with time and move with the glacier. They can be identified in two separate Landsat images (path 118/row 107, ident 1129-01360, date 29 November 1972; and $119 / 107,1580-01364,23$ February 1974) which have an intervening time interval of 1.24 year.

The two images are registered digitally using, as tie points, exposed rock features which are sharply defined in both images and are supplemented by a number of less well-defined features. The tie points are distributed unevenly over the images and are generally clustered around major rock outcrops in the area. A second-order polynomial is used to warp (or map) one image to the other, and errors at the tie points are typically of the order of one pixel $(60-80 \mathrm{~m}$ for Landsat MSS data). Away from the tie points, there is some residual mismatch in the images, which is taken into account when calculating the velocities.

The moving features common to the two registered images are identified visually on an image-display system and their digital coordinates are extracted. The velocity is then the displacement of the feature over the intervening time interval. For sharply defined features, the measurement accuracy of the displacement of surface features is about one pixel, which is equivalent to $\pm 64 \mathrm{~m} \mathrm{a}^{-1}$ in velocity. In practice, there are few points of this quality and many more of a diffuse nature. The relative consistency of the values along a $100 \mathrm{~km}$ section between Mount Strathcona and Cape Jones indicates a resultant accuracy of better than $\pm 100 \mathrm{~m} \mathrm{a}^{-1}$ (i.e. one and a half pixels on the digital images). Features on the glacier tongue are more diffuse and the accuracy of the velocities is estimated to be about $\pm 100 \mathrm{~m} \mathrm{a}^{-1}$.

The study successfully produced a set of 120 velocity vectors distributed along Denman Glacier and over the neighbouring Shackleton Ice Shelf with sufficient accuracy that many glaciological features can be clearly discerned. The velocity of the ice stream increases from $400-500 \mathrm{~m} \mathrm{a}^{-1}$ opposite Mount Strathcona to $1550-1650 \mathrm{~m} \mathrm{a}^{-1}$ opposite Cape Jones, where it begins to float, then decreases to values in the range $1250-1550 \mathrm{~m} \mathrm{a}^{-1}$ near the outer edge. Cheremnikh (1963), gave values in the range $1241-1460 \pm 7 \mathrm{~m} \mathrm{a}^{-1}$ west of Chugunov Island obtained from repeated phototriangulation surveys. These are almost identical to the values of $1250-1450 \mathrm{~m} \mathrm{a}^{-1}$ found by this work in a similar area. But the velocity near Cape Jones is 50\% larger than the values proposed by Dolgushin (1963) on the basis of morphological characteristics of the ice stream. Values along an $80 \mathrm{~km}$ long cross-section $35 \mathrm{~km}$ north of Cape Jones show the variation in velocity across the ice stream and neighbouring ice shelf. The velocity increases from about $1100 \mathrm{~m} \mathrm{a}^{-1}$ in the west on the inside of a bend in the ice stream to a maximum of $1600 \mathrm{~m} \mathrm{a}^{-1}$ on the outside of the bend, then falls sharply to $450-550 \mathrm{~m} \mathrm{a}^{-1}$ in slower-moving ice further east. On the grounded part of the ice stream, there are two zones of increased longitudinal strain-rate centred about 25 and $55 \mathrm{~km}$ inland from Cape Jones. They coincide with two zones of steeper surface slope on the ice stream which can be identified on topographic maps of the area (Tolstikov, 1966).

This set of measured velocities on Denman Glacier represents the most extensive set of movement data along the length of a major outlet glacier stream in East Antarctica which covers both the flow through the grounded ice sheet and out through the floating ice shelf. The velocities and analysis of the data will be presented in a fuller paper later. It is intended to continue this work on other glacier streams using existing pairs of images and as new data become available.

\section{ACKNOWLEDGEMENTS}

The development of the rectification and digital analysis techniques for glacier movement was carried out in collaboration with S. Jones from the Centre for Spatial Information Systems of the CSIRO Division of Information Technology.

\section{REFERENCES}

Cheremnykh, G.D. 1963. Yeshche o metodike opnedeleniya skorosti doizheniya poverkhnosti lednika po materialam aerofotos"yemki [Some additional remarks about the methods of determination of movement velocities of the glacier's surface according to the materials of the aerophoto survey]. Rezul't. Issled. Programme Mezhdunar. Geofiz. Goda. Glyatsiol. Issl., 9, 179-182.

Dolgushin, L.D. 1963. Skorosti dvizheniya lednikov Antarktidy po povtornym aerofotos"yemkam i morfologicheskim priznakam [Movement velocities of Antarctic glaciers according to repeated aerial photographic surveys and morphological data]. Rezul't. Issled. Programme Mezhdunar. Geofiz. Goda, Glyatsiol. Issl., 9, 164-178.

Lucchitta, B.K. and H.M. Ferguson. 1986. Antarctica: measuring glacier velocity from satellite images. Science, 234(4780), 1105-1108.

Tolstikov, Ye.I., ed. 1966. Atlas Antarktiki. I. [Antarctic atlas. I]. Moskva, Glavnoye Upravleniye Geodezii i Kartografii MG SSSR. 